\title{
The Effectivity of TPS Type Cooperative Learning Model Based on Interpersonal Intelligence Toward Mathematical Knowledge Competencies
}

\section{G.N. Sastra Agustika ${ }^{1}$, Ni Md. Ayu Aryati², I Wyn. Wiarta ${ }^{3}$}

${ }^{123}$ Universitas Pendidikan Ganesha

\section{A R T I C L E I N F 0}

Article history:

Received 15 May 2019

Received in revised

form

29 June 2019

Accepted 18 July 2019

Available online 29

August 2019

Keywords:

Think Pair Share,

Interpersonal

Intelligence,

Mathematics

\begin{abstract}
A B S T R A C T
This study aimed to find out the effectiveness of cooperative learning model of the Think Pair Share type observed from interpersonal intelligence toward Mathematical competency on the fourth grade at SDN Moh. Hatta in academic year of 2018/2019. This study was a quasi-experimental design with $2 \times 2$ factorial design. The population of this study were 244 students on the fourth grade of SDN Moh. Hatta in academic year of 2018/2019. The sample technique used in this study was purposive sample.The data were collected using test and non-test methods. The data were analysed using 2-lane variance analysis. Based on the results of the analysis, it is obtained that (1) $F_{A \text { hitung }}=$ $\left.7,002>F_{\text {tabel }}(\alpha=0,05 ; 1 ; 76)\right)=3,967$. Therefore, the null hypothesis $\left(H_{0}\right)$ is rejected. It signifies that "there is a significant difference in Mathematical competency between group of students who are taught through cooperative learning model of Think Pair Share type and group of students who are taught using conventional learning", (2) $F_{B}$ hitung $=$ $0,041<F_{\text {tabel }(\alpha=0,05 ; 1 ; 76))}=3,967$. Therefore, the null hypothesis $\left(H_{0}\right)$ is accepted. It means that "there is no significant difference in Mathematical competency between students who have high interpersonal intelligence and students who have low interpersonal

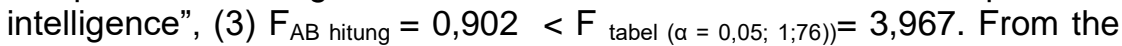
last results, the null hypothesis $\left(\mathrm{H}_{0}\right)$ is accepted. It means that "there is no significant interaction between cooperative learning model of Think Pair Share type and interpersonal intelligence on Mathematical competency. The results of the treatment effectiveness calculation obtained the score of $\eta^{2}=0.083$. Overall, it can be concluded that the application of the learning model has an influence on the Mathematical competency by $8,3 \%$
\end{abstract}




\section{Introduction}

Education is a conscious and planned effort that purposed to educate a nation's generation. In education students are taught various subjects, one of them is mathematics. Mathematics is one of the lessons that must be mastered by the students; since, according to the Indonesian Government Education's regulation named Permendikbud Number 57 in 2014, "the ability to master Mathematics is a part of life skills that must be had by the students, especially in developing logical thinking, communication, and problem solving skill in their daily lives." However, based on the data obtained after observing the Department of Education for Youth and Sports in South Denpasar District conducted data that the results of the 2017/2018 national school year, especially on mathematics subjects, which scored the lowest compared to other subjects, with an average score of 65,66 with the lowest score obtained by students 3,3 and the data obtained from fourth grade teachers at Public Elementary Schools in Muh. Hatta Group in the learning process of Mathematics still had many obstacles that affected students' mathematical knowledge competencies. These obstacles occurred in the learning process because of the lack of interaction between students and other students, and also students with their learning resources. As a result, the students were less active in the mathematic class participation.

Mathematical competency will increase if the students' motivation in learning Mathematics increases. The Think Pair Share cooperative learning model is thought to increase students' motivation since it provides thinking time to improve the quality of student responses, making students more active in thinking about subject concepts and each student has the opportunity to express his/her opinion, in order to develop an optimistic students' participation. In the use of the co-operative model type Think Pair Share, social skills are needed in asking questions, answering and listening. So, interpersonal intelligence is very influential in this model, because it is able to support the students in achieving the expecting competencies.

Group learning is often known as the cooperative learning model. One of the types of cooperative learning is Think Pair Share (TPS). "This strategy introduces the idea of waiting or thinking time on the interaction elements of cooperative learning which is currently one of the powerful factors in reminding students' responses to questions." (Huda, 2013: 206). In Cooperative learning type, Think Pair Share requires skills in communication, because group-based learning requires good communication within the group. So, in this case the ability to communicate includes the components that support the learning process. The ability to communicate is often known as social intelligence or interpersonal intelligence. According to Safaria (2005: 23), "Children who are high in interpersonal intelligence will be able to establish effective communication with others." As a result, students with high interpersonal intelligence will prefer to study in groups, since they have an ability to communicate effectively with others.

The purposes of this study were; 1) Finding out the significant differences in Mathematical competencies between students who were taught using the Think Pair Share type of cooperative learning model and students who were taught using conventional learning models. 2) Finding out the significant differences in Mathematical competencies between students who had high interpersonal intelligence and students who had low interpersonal intelligence on Mathematical competencies. 3) Determining the interaction of the cooperative learning model of the Think Pair Share type and interpersonal intelligence on the fourth grade students' Mathematical competencies at Public Elementary School in Moh. Hatta Group in 2018/2019

\section{Methods}

This study was a quasi-experimental design with $2 \times 2$ factorial design. The population of this study was fourth grade students of Public Elementary School in Moh. Hatta Group in 2018/2019 that consisted of 244 students.

Table 1 Fourth Grade Students' Population Composition at Public Elementary Schools in Moh. Hatta Group in 2018/2019 at South Denpasar Distric

\begin{tabular}{lllc}
\hline No & School & Class & Number of Sudents \\
\hline 1 & SDN 1 Panjer & IV & 40 \\
2 & SDN 2 Panjer & IV & 39 \\
3 & SDN 3 Panjer & IV & 40 \\
4 & SDN 4 Panjer & IV & 43 \\
5 & SDN 6 Panjer & IV A & 41 \\
\hline
\end{tabular}




\begin{tabular}{lll}
\hline & IV B & 41 \\
\hline Number & & 224 \\
\hline
\end{tabular}

After investigating the population, the next step was determining the research sample. The sampling technique used was Non-probability Sampling, namely Purposive Sampling. Based on certain considerations and school policies, research can only be done in 4 classes from 3 schools. So, the classes that used as the research sample were the classes from the schools that gave the access to conduct research. To choose the control class and the experimental class, it was done randomly. Public Elementary Schools selected as the control group were fourth grade of SD Negeri 4 Panjer which amounted to 43 students and Public Elementary Schools who were selected as the experimental group were fourth grade students of SD 6 Panjer, especiallt the IVA Class. The class was consisted of 40 students.

The Data were collected using test methods, namely ordinary and non-test MCQs, especially questionnaires. In this study, the experimental group and the control group were given interpersonal intelligence and questionnaires and pretest, followed by treatment as many as 6 meetings, then given posttest. The results of the questionnaire data were analyzed to determine interpersonal intelligence scores which were then categorized as groups of students with high interpersonal intelligence and groups of students with low interpersonal intelligence using the median limit. Before the process of categorizing interpersonal intelligence in 3 samples with too low a range of scores was not analyzed, so that high interpersonal intelligence in the control group and the experimental group was equivalent, low interpersonal intelligence in the control group and experimental groups was equivalent, and high and low interpersonal intelligence in each group was different.

Hypothesis testing is done by analyzing the gain score data obtained from the results of the pretest and posttest using 2-lane variance analysis. To be able to use the variance 2 -way analysis technique, it is necessary to analyze the prerequisites that must be met, namely the normality and homogeneity test. The normality test is carried out by the Kolmogorov Smirnov test while the homogeneity test is carried out by the Bartlett test. After testing the hypothesis to find out how much was the influence of the independent variable on the dependent variable in the sample. In this study the effectiveness of the treatment was calculated using eta square.

\section{Result And Discussion}

Scores of interpersonal intelligence scores of control group students are presented in figure 1.

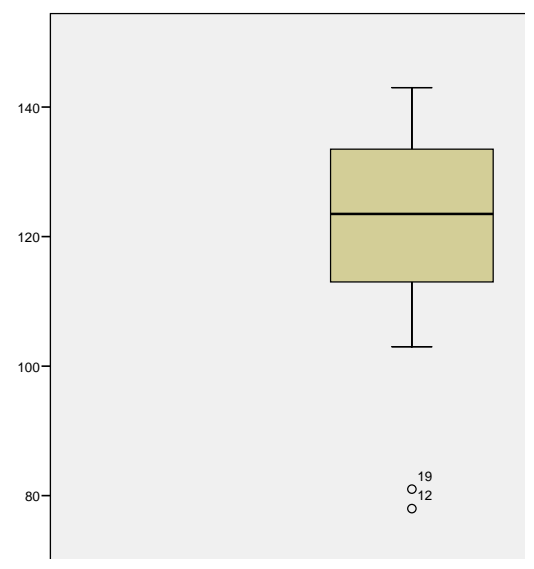

Figure 1. Intelligence Box Plot Graph Interpersonal Control Group

Based on the Box Plot graph in figure 01, the median boundary showed that the median limit of interpersonal intelligence of the control group students was 123.5. So, students who were categorized as groups with high interpersonal intelligence were students with interpersonal intelligence scores of more than 123.5. Meanwhile, students who categorized as groups with low interpersonal intelligence were the students with interpersonal intelligence scores that were less than 123.5. The maximum value of the control group's interpersonal intelligence was 143 and the minimum value was 78 . 


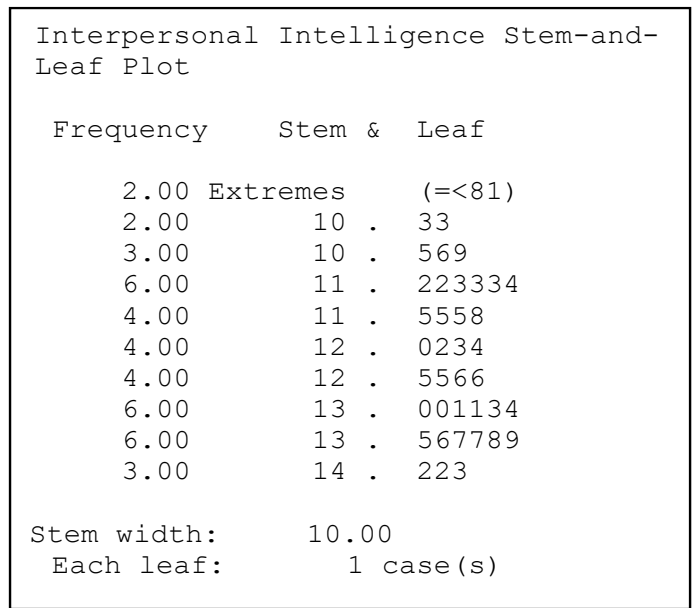

Figure 2 Graph of Steam and Leaf Interpersonal Intelligence Control Group

From figure 2 it could be seen the number of extreme data, which were as much as 2 data, and the data that appeared the most were data with a range of scores 112-114 as many as 6 data, a range of scores 130-134 as much as 6 data, and a range of scores 135-139 as many as 6 data.

Scores of interpersonal intelligence scores of control group students are presented in figure 3

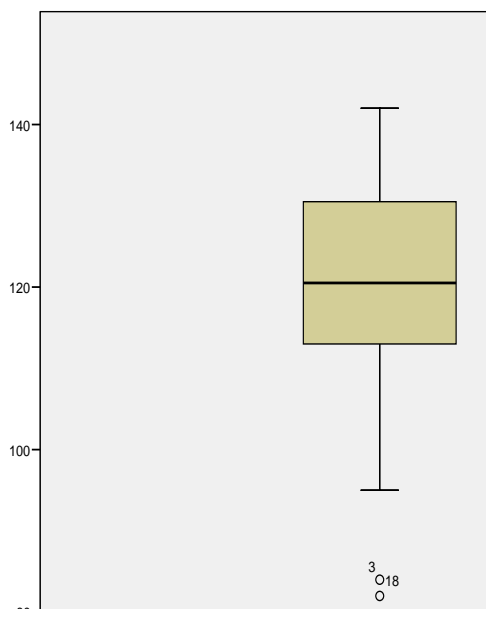

Figure 03 Box Plot Interpersonal Intelligence Graph Experimental Class

It was known that the median limit of interpersonal intelligence of the control group students was 120.5. Thus, students who were categorized as groups with high interpersonal intelligence were students with interpersonal intelligence scores greater than 120.5. Meanwhile, students who were categorized as groups with low interpersonal intelligence are students with interpersonal intelligence scores smaller than 120.5. The maximum value of the interpersonal intelligence of the experimental group was 142 and the minimum value was 82 . 


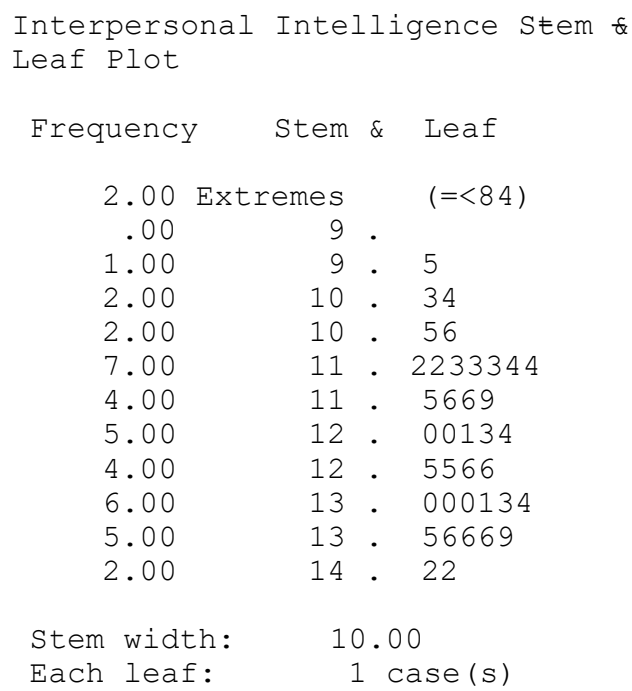

Figure 4 Graph of Steam and Leaf Interpersonal Intelligence Experimental Group

From figure 4, we could find the number of extreme data, which was as much as 2 data, and the data that appeared the most was data with a range of scores of 112-114 of 7 data. To find out the equality of interpersonal intelligence of the control group students and the experimental group were tested using the Independent Two Sample T-test. The results of the Independent Two-Sample T-Test were presented in Table 2.

Table 2. Data results of the Independent Two-Sample T-test

\begin{tabular}{|c|c|c|c|c|c|}
\hline No & Category & $\mathrm{T}_{\text {count }}$ & $\mathrm{T}_{\text {tabel }}$ & Decision & Notes \\
\hline 1 & $\begin{array}{l}\text { High Intelligence of Control } \\
\text { Class and Experiment Class }\end{array}$ & 0,99847 & 2,02439 & $\mathrm{H}_{0}$ accepted & $\begin{array}{l}\text { There was no } \\
\text { difference between } \\
\text { the high Intelligence } \\
\text { of Control Class and } \\
\text { Experiment Class }\end{array}$ \\
\hline 2 & $\begin{array}{l}\text { Low Intelligence of Control Class } \\
\text { and Experiment Class }\end{array}$ & 0,19136 & 2,02439 & $\mathrm{H}_{0}$ accepted & $\begin{array}{l}\text { There was no } \\
\text { difference between } \\
\text { the low Intelligence } \\
\text { of Control Class and } \\
\text { Experiment Class }\end{array}$ \\
\hline 3 & $\begin{array}{l}\text { High Intelligence of Control } \\
\text { Class and Low Intelligence of } \\
\text { Control Class }\end{array}$ & 7,83373 & 2,02439 & $\mathrm{H}_{0}$ refused & $\begin{array}{l}\text { There was } \\
\text { difference between } \\
\text { the high Intelligence } \\
\text { of Control Class and } \\
\text { Low Intelligence of } \\
\text { Control Class }\end{array}$ \\
\hline 4 & $\begin{array}{l}\text { High Intelligence of Experiment } \\
\text { Class and Low Intelligence of } \\
\text { Experiment Class }\end{array}$ & 7.80372 & 2,02439 & $\mathrm{H}_{0}$ refused & $\begin{array}{l}\text { There was } \\
\text { difference between } \\
\text { the High Intelligence } \\
\text { of Experiment Class } \\
\text { and Low Intelligence } \\
\text { of Experiment Class }\end{array}$ \\
\hline
\end{tabular}

Based on Table 2 it was concluded that high inter-perpetic intelligence in the control group had no difference with high intelligence in the experimental group. Low interpersonal intelligence in the control group there was no difference with low interpersonal intelligence in the experimental group. There were differences in high and low interpersonal intelligence in the control group. There were differences in high and low interpersonal intelligence in the experimental group 
After knowing the results of the equality of interpersonal intelligence of the control group and the experimental group, the data were analysed using the pre-test and post-test results. The data from the pre-test and post-test of the control group were presented on the steam and leaf charts as in Figure 5 and Figure 6.

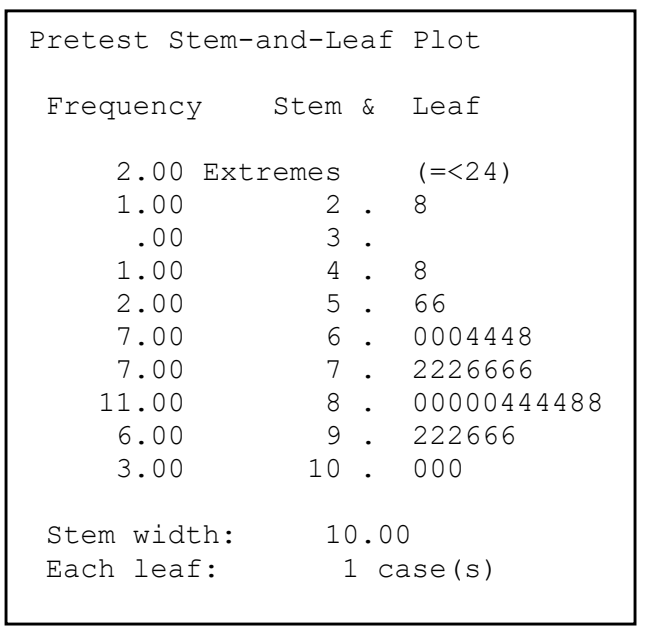

Figure 05. Graph of Pretest Control and Steam Data Leaf Groups

Based on figure 05, it was known that the data from the pretest control group with the number of extremes data were $\leq 24$ as many as 2 data. The minimum value was 24 as many as 2 data, the maximum value was 100 as much as 3 data and the largest range of values is $80-88$ by 11 data.

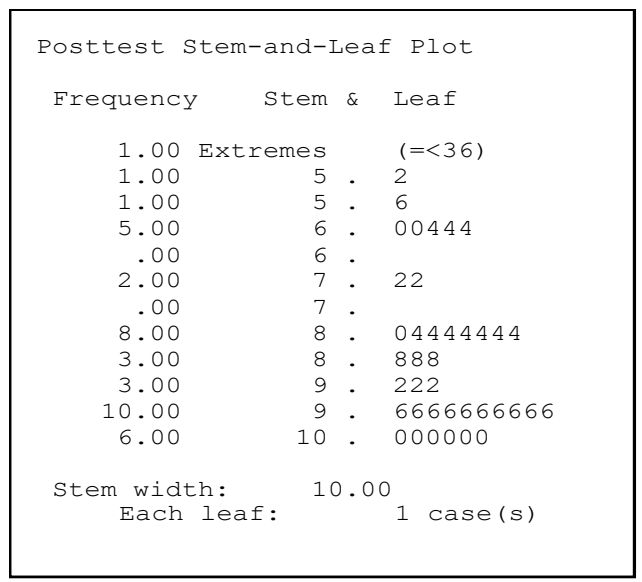

Figure 6. Graph of Steam and Leaf Data Posttest Control Group

Based on figure 6, it was known that the posttest data of students who were taught by conventional learning models with the number of extremes data were $\leq 36$ as many as 1 data. The minimum value was 36 as many as 1 data, the maximum value was 100 as many as 6 data and the highest value was 96 as many as 10 data.

Data from the pretest and posttest experimental groups were presented on the steam and leaf charts as in Figure 7 and Figure 08 


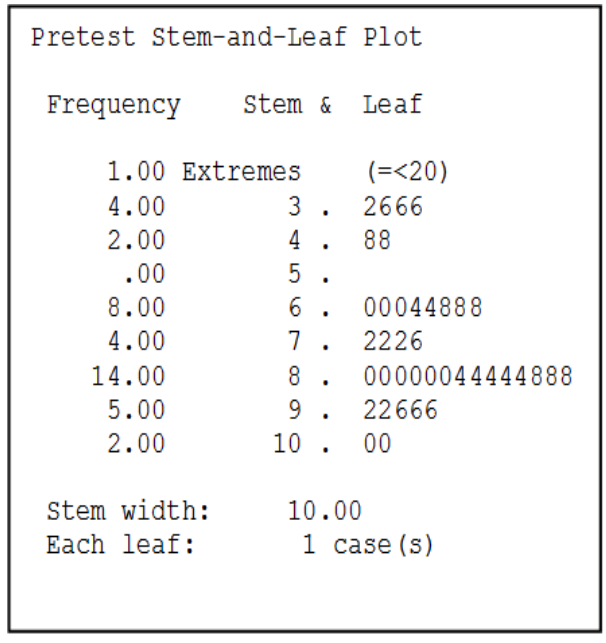

Figure 7.Graph of Pretest Steam and Leaf Data Experimental Groups

Based on Figure 7 it was known that the data from the pretest of the experimental group with the number of extremes data was $\leq 20$ as much as 1 data. The minimum value was 20 as many as 1 data, the maximum value was 100 as much as 2 data and the highest value was $80-88$ as much as 14 data.

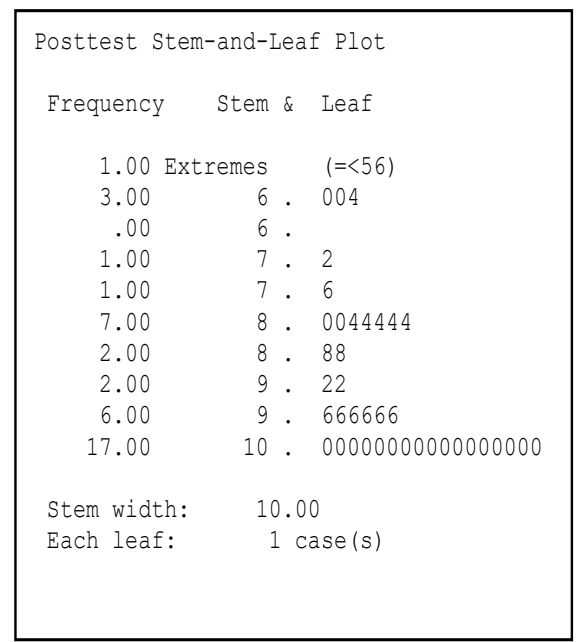

Figure 8 Graph of Steam and Leaf Posttest Data of Experimental Groups

Based on Figure 8, the data from the posttest results of the experimental group with the number of extremes data were 56 as much as 1 data. The minimum value was 56 as many as 1 data, the maximum value is 100 as much as 17 data and the highest value is 100 as much as 17 data.

After knowing the value of the pre-test and post-test of the control group and the experimental group, the data values of the pretest and posttest were then analyzed to obtain the gain score.

After obtaining the data gain score, the data gain score normality test and homogeneity test for the four groups were obtained. The results of the normality data distribution score test are presented in Table 3.

Table 3. Normality Test Results Data Gain Score Control Group and Student Experiment Group with High and Low Interpersonal Intelligence

\begin{tabular}{llllll}
\hline No Group & & Maximum & \multicolumn{2}{l}{$\begin{array}{l}\text { Value } \\
\text { Kolmogorov- } \\
\text { Smirnov }\end{array}$} & Notes \\
\hline 1 & The Experiment Group with high & 0,256 & 0,294 & $\begin{array}{l}\text { normal } \\
\text { distribution } \\
\text { interpersonal Intelligence students } \\
\text { normal }\end{array}$ \\
\hline
\end{tabular}




\begin{tabular}{lllll}
\hline No Group & $\begin{array}{l}\text { Maximum } \\
\text { Score } \\
\left|\mathrm{F}_{\mathrm{T}}-\mathrm{F}_{\mathrm{S}}\right|\end{array}$ & $\begin{array}{l}\text { Value } \\
\text { Kolmogorov- } \\
\text { Smirnov }\end{array}$ & Notes \\
\hline $\begin{array}{l}\text { interpersonal Intelligence students } \\
3\end{array}$ & & 0,294 & $\begin{array}{l}\text { distribution } \\
\text { normal } \\
\text { distribution }\end{array}$ \\
$\begin{array}{l}\text { The Control Group with hersonal Intelligence students } \\
\text { interpersh }\end{array}$ & 0,218 & & $\begin{array}{l}\text { normal } \\
\text { distribution }\end{array}$ \\
\hline $\begin{array}{l}\text { The Control Group with high } \\
\text { interpersonal Intelligence students }\end{array}$ & 0,271 & 0,294 & \\
\hline
\end{tabular}

The testing criteria were; if the maximum value was $\leq$ the value of the Kolmogorov-Smirnov table, then the data was normally distributed. Conversely, if the maximum value was $>$ the value of the Kolmogorov-Smirnov table, then the data was not normally distributed. Based on table 03, it could be concluded that data was normally distributed.

Homogeneity tests were carried out to show that the results obtained from the 2-lane variance analysis test actually came from differences between groups not because of differences in groups. To test the variance homogeneity of the four groups was used the Bartlett test as in Table 4.

Table 4. Test of Homogeneity of the Fourth Group Variance

\begin{tabular}{lrl}
\hline Score $\chi_{\text {count }}^{2}$ & Score $\chi_{\text {table }}^{2}$ & Explanation \\
\hline 3,609 & 7,815 & Homogen \\
\hline
\end{tabular}

From the calculation results obtained $\mathrm{F}$ count $=3,609$ While $\mathrm{F}$ table $=7,815$ With a significance level of $5 \%(\alpha=0,05)$ with degrees of freedom $4-1=3$. Then the value of $F$ count $=3,609<F$ table $=7,815$ which concluded that the data of the two groups had a homogeneous variance.

The Data that had been tested for normality and homogeneity were carried out statistical tests with 2-way variance analysis. The hypothesis tested was 1) Ho: There was no significant difference in Mathematical competencies between students who were taught using the Think Pair Share type of cooperative learning model and students who were taught using conventional models. 2) Ho: There was no significant difference in Mathematical competencies between students who had high interpersonal intelligence and students who had low interpersonal intelligence on Mathematics competencies. 3) Ho: There was no significant interaction between the cooperative pair type Think Pair Share and interpersonal intelligence on the fourth grade elementary mathematics competencies of Moh. Hatta Group's students.

The recapitulation of the results of the analysis of the variance of the 2 lines of this research sample group wass presented in Table 5.

Table 05. Recapitulation of the results of analysis of variance in 2 lines of the Research Sample Group

\begin{tabular}{lllllcl}
\hline Variance source & $D b$ & $\mathrm{JK}$ & $\mathrm{MK}$ & $\mathrm{F}$ count & $\mathrm{F}_{\text {table }}(5 \%)$ & Decisson \\
\hline Between A & 1 & 1216,80 & 1216,80 & 7,002 & 3,967 & $\mathrm{H}_{0}$ refused \\
Between B & 1 & 7,20 & 7,20 & 0,041 & 3,967 & $\mathrm{H}_{0}$ accepted \\
A x B Interaction & $1 \times 1$ & 156,80 & 156,80 & 0,902 & 3,967 & $\mathrm{H}_{0}$ accepted \\
Inside & 76 & 13208,00 & 173,789 & - & - & - \\
Total & 79 & 14588,80 & - & - & - & - \\
\hline
\end{tabular}

Based on the results of the analysis listed in the summary table of the two-way variance analysis, conclusions could be drawn as follows. 1) FA count $=7,002>3,967$, so the null hypothesis (Ho) which stated there was no significant difference was rejected. This means that there were significant differences in Mathematical knowledge competencies between students who were taught using the Think Pair Share type cooperative learning model and students who were taught using conventional models. In other words, the cooperative learning model of the Think Pair Share type influenced the mathematical competencies of the fourth grade students of Public Emelentary School in Moh. Hatta group. Viewed from the gain score average, it showed that the Mathematical competencies of the group of students who were 
taught using the cooperative learning model Think Pair Share $A_{1}=17,70>A_{2}=9,9$ groups of students who were taught using conventional learning models. From the data on the acquisition of Mathematics competencies in the experimental group and the control group that the competency of knowledge of students who were taught using the Think Pair Share cooperative learning model was better because Think Pair Share cooperative learning model provided time for individual thinking to improve the quality of student responses so that they were active in thinking regarding concepts in subjects, students better understand the concept of topic lessons during discussions in pairs, each student in his group has the opportunity to share or convey ideas and also because of the weaknesses of conventional models namely learning went boring, students became passive and only writing, then, since the students were passive, the knowledge obtained was easily forgotten.

2) $\mathrm{FB}$ count $=0,041<3,967$, so the null hypothesis (Ho) which stated there was no significant difference was accepted. This means that there was no significant difference in Mathematics competencies between students who had high interpersonal intelligence and students who had low interpersonal intelligence on Mathematics competencies. This was because interpersonal intelligence was a person's ability to communicate with others. Students' mathematical competencies were not measured by students' ability to communicate about mathematics verbally to others, but based on students' ability to understand mathematical concepts so they could solve math problems well. Thus, interpersonal intelligence had no influence on the competencies of Mathematics

3) FAB count $=0,902<3,967$, so that the null hypothesis (Ho) which stated there were no significant interactions received. This means that there wass no significant interaction between the cooperative learning model of the Think Pair Share type and interpersonal intelligence on the Mathematics competency of fourth grade students in Moh. Hatta Elementary School Group. Viewed from the average value of the gain score of students taught by cooperative learning models of the Think Pair Share students with low interpersonal intelligence is 16,60 and students with high interpersonal intelligence were 18,80 while the group of students who erre taught with conventional learning models of students with Low interpersonal intelligence is 11,60 and students with high interpersonal intelligence were 8,20 from the gain score average students who were taught by the cooperative model Think Pair Share have a higher gain score than students who are taught using conventional learning, both in high and low interpersonal intelligence. This was because interpersonal intelligence was a person's ability to communicate with others, students' mathematical competencies were not measured by students' ability to communicate about mathematics verbally to others, but based on students' ability to understand mathematical concepts so they could solve math problems well and also interpersonal intelligence that students had enough students to teach students with the cooperative learning model of Think Pair Share both students with high and low interpersonal intelligence.

There was no significant interaction between the cooperative learning model type Think Pair Share and interpersonal intelligence on Mathematics competencies were visualized graphically in figure 9 below.

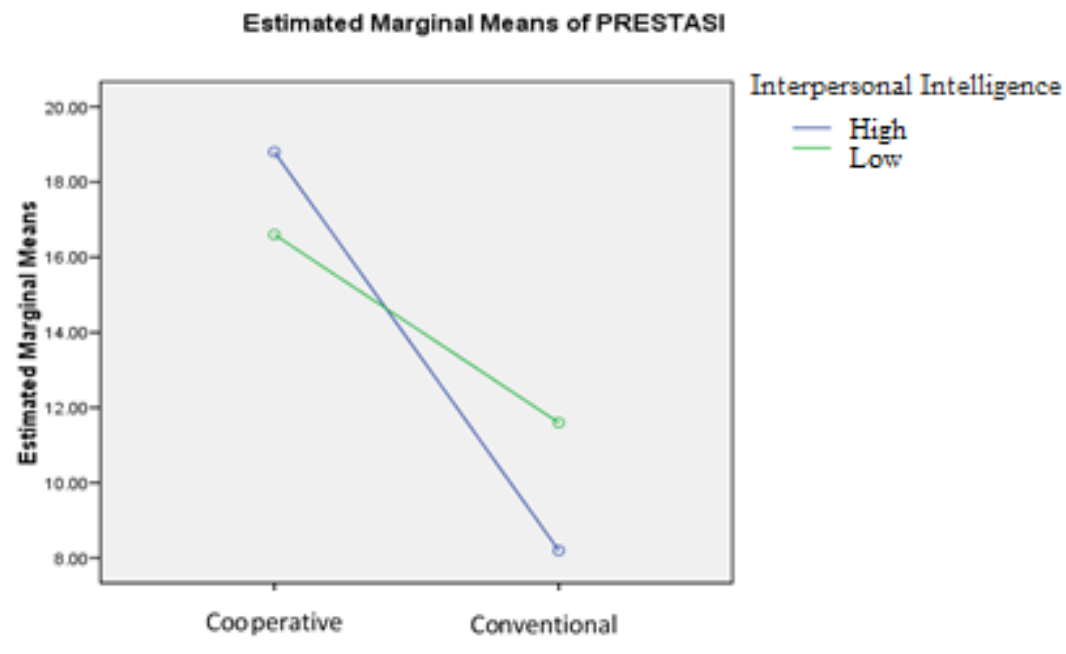

Figure 9 Graph of Interaction Learning Model and Interpersonal Intelligence 
Based on Figure 9, the learning model and interpersonal intelligence did not have a significant interaction so it was not followed up by further cell testing. Based on the testing of the first hypothesis, the results showed that there was a significant effect of the cooperative learning type Think Pair Share on the knowledge competency of Mathematics. The magnitude of the influence of the model on the knowledge competencies of Mathematics could be determined by calculating the effectiveness. From the results of the eta square calculation, the value of 0,083 was obtained. So, it could be concluded that the application of the learning model had 8,3\% influences on Mathematical competencies.

\section{Conclussion}

In accordance with the results of the study and discussion, it could be concluded as follows (1) Based on the calculation of FA count $=7,002>$ F table $(\alpha=0,05 ; 1 ; 76))=3,967$ so the null hypothesis (Ho) states that there was no significant differences in Mathematical competencies between students who were taught using the Think Pair Share type cooperative learning model and students who were taught using conventional models were rejected. This means that overall there were significant differences in Mathematical competencies between groups of students who are taught using the cooperative learning model type Think Pair Share with groups of students who are taught using conventional learning. 2) Based on the calculation of FB count $=0,041<$ F table $(\alpha=0,05 ; 1 ; 76))=3,967$ so that the null hypothesis (Ho) states that there was no significant difference in Mathematics competencies between students who had high interpersonal intelligence and students those who had low interpersonal intelligence are accepted. This means that overall there was no significant difference in Mathematical competencies between students who had high interpersonal intelligence and students who had low interpersonal intelligence on Mathematics competencies. Thus the knowledge competency of Mathematics students who had high interpersonal intelligence is not necessarily better with students who have low interpersonal intelligence. 3) Based on the calculation of FAB count $=0,902<$ F table $(\alpha=0,05 ; 1 ; 76))=3,967$ null hypothesis (Ho) which states that there is no significant interaction between the Think Pair Share type cooperative learning model and interpersonal intelligence on competence Mathematics knowledge of fourth grades of SD Moh.Hatta Group was accepted. This means that overall there was no significant interaction between the cooperative learning model type Think Pair Share and interpersonal intelligence on Mathematics competency of fourth grade students in Moh. Hatta Elementary School Group.

According to the results of the research that has been concluded, there were a number of suggestions presented to various parties as follows. 1) Teachers should be able to add insight into learning innovations so that they are able to apply and develop classroom learning in a more innovative and varied manner in order to have a positive impact on increasing knowledge competencies. One of the learning models that can be recommended for teachers in creating varied learning is the cooperative pair type Think Pair Share model. The teachers also should be able to enhance their role as a motivator and facilitator. 2) Principals should be able to contribute fully in improving quality and optimizing the learning process, so that it has a positive impact on students' competencies especially in elementary schools. 3) Based on research findings, the results of this study are expected to be used as references to carry out further research or find other innovative learning activities that are meaningful for the students.

\section{Reference}

Huda, Miftahul. 2013. Model-model Pengajaran dan Pembelajaran : Isu-isu Metodis dan Paradigmatis. Yogyakarta : Pustaka Pelajar.

Olejnik, Stephan. 2003. “Generalized Eta and Omega Squared Statistics: Measures of Effect Size for Some Common Research Designs". The American Psychological Association, Inc, Volume 8, Nomor 4 (hlm 435). (diakses pada tanggal 20 Januari).

Permendikbud. 2014. Peraturan Menteri Pendidikan dan Kebudayaan Republik Indonesia Nomor 57 Tahun 2014 Tentang Kurikulum 2013 Sekolah Dasar/Madrasah Ibtidaiyah. Jakarta : Kemendikbud.

Riduwan. 2008. Metode \& Teknik Menyusun Tesis. Bandung : Alfabeta.

Safaria. 2005. Metode Pengembangan Kecerdasan Interpersonal Anak. Yogyakarta : Amara Books.

Tuckman, B.W.1999. Conducting Education Research. New York : Harcourt Brace Jovanivich. 